Linguistik Terapan 14(3) (2017): 282-287

Jurnal Linguistik Terapan Pascasarjana

Available online http://jurnal.unimed.ac.id/2017/index.php/JLT-

Unimed

\title{
THE LANGUAGE MAINTENANCE OF BALINESE IN LANGKAT
}

\author{
Ramadani \\ Sumarsih
}

Busmin Gurning

Diterima September 2017; Disetujui Oktober 2017; Dipublikasikan Desember 2017

\begin{abstract}
This study deals with the language maintenance of Balinese in Langkat. This objective of the study was to examine the factors affecting the Balinese language maintenance in Langkat. This study was descriptively qulitatively conducted. The subjects taken were 20 males and females of Balinese. The use of instruments in this study were interview to gain the factors of Balinese language maintainance in Langkat. The theories of Holmes was used in this study. The data were analyzed by using Spradley analysis (1979). There are seven factors affecting Balinese language maintenance in the first and the second generation of Balinese in Langkat found as the findings of the study such as; ethno linguistic vitality, using language in family domain, using language in neighborhood domain, using language in religion domain, using language in workplace domain, practice of traditional ceremony and an additional factor that found by researcher as a new insight in this research is interaction with older people. Analysis of data clearly indicates that Balinese language maintenance were done in Langkat.
\end{abstract}

Keywords: language maintenance, factors affecting language maintenance, Balinese in Langkat

How to Cite: Ramadani (2017). The Language Maintenance of Balinese In Langkat. Jurnal Linguistik Terapan Pascasarjana Unimed, 14 (3): 282-287

ISSN 2407-7410

\section{INTRODUCTION}

Language is tool communication people use language to communicate with each other. They can express their mind with communication. Language is important part of human express their ideas. Indonesia has many ethnics group and indegenous languages. Especially in Langkat North Sumatera, there are many ethnics group in Langkat such as Javanese, Malayanese, Banjarnese, Bataknese, Chinese and Balinese. The native inhabitants of Langkat is Malayanese and the ethnics group that migration in Langkat such as Javanese, Bataknese, Banjarnese and Balinese. Balinese is minority group in Langkat, especially in Paya Tusam Village, because the majority is javanese. Although, 
Balinese is a minority group, but they can maintain their language. They use their language in daily communication. In Langkat, Balinese is a very minority than another ethnic group.

The phenomenon of Balinese in Langkat, Balinese had lived in Langkat since 1974. Language maintenance mostly occurs in countries where mostly visited by immigrants who want to start a better life there. The immigrants of balinese in Langkat are caused by Agung erruptions in February 1963. Due to that erruptions, the citizens lost their source of life. In that time, the Balinese transmigrate in some islands to make their life better. One of those islands are Sumatera, especially in North Sumatera. I Nengah Sambe is the first generation of Balinese people in that village. I Nengah said, the begining of Balinese consists five families. The five families are the first generation living in Langkat in 1974. Two years later, the other Balinese people worked as employee in plantation Tanjung Gerbus, Deli Serdang. Balinese comes with bigger number to this village, so the number of Balinese people become families. Finally, Paya Tusam is known by Kampung Bali.

Although, Balinese is a minority group in Langkat, they can maintain their language and culture. They still do traditional culture like mecaru. Mecaru is a tradition ceremony, that has an aim to harmony of bhuwana agung (universe) and bhuwana alit (human being) to be good, beautiful, and sustainable.

Language must be maintained because language showed the identity of the language users. As Holmes (2008:174) states that where language is considered as important symbol of a minority groups' identity, the language is likely to be maintained longer. Moreover, Corson (2002:174) said that the maintenance of a heritage language is vital for the self-identity and esteen of its speakers. Therefore, language must be protected, perserved, and maintained.

Based on the observation above, the young generation can maintain their langauge. They use Balinese language in daily communication. They have awareness to use Balinese language. They also have solidarity to use their language to keep their ethnic group. In this condition is found that Balinese family who live in Langkat competent to due to regeneration of their vernicular to their generation because their generation competent in using active Balinese in daily communicaton. Although some of them more often use Indonesia language than Balinese language. As Djamereng (2014) indicates that factor of attitude contributing to the maintenance of Balinese language among transmigrant communities, language maintenance of the Balinese language occurs in transmigration until this time because of some factors. However this condition will not take place for a long time if there is no continuity of the use of mother tongue to the third generation. Therefore, parents need to inherit the language to the next generation. It is in line with Liberson (1980:17) who promoted the language maintenance through intergeneration process and it is the process of shifting language use from first generation to next generation.

It is also similarly to the generation of Balinese in Langkat, they can speak Balinese language but they more often used Indonesia language than Balinese language. It means that when Balinese is not a dominant language in communication. It will be endangered. The using of Indonesia language 
made the decrease of Balinese speakers in Langkat. It is important to conduct a study on Balinese in Langkat. There are some factors, ways, and reason to maintain Balinese. As Holmes (2008), there are some factorsin maintaining the language, they are ethno linguistic vitality, living together and see other frequently, intra mariage, using language in family domain, using language in neighborhood domain, using language in religion domain, using language in education domain, using language in workplace domain, practice of traditional ceremony.

\section{RESEARCH METHOD}

This research method was applied qualitative research design (Bogdan \& Biklen, 1992:58). This study was designed based on descriptive qualitative. Qualitative research is a system of inquiry which seeks to build a holistic, largely narrative, description to inform the researcher's understanding of a social or cultural phenomenon.

Qualitative research consists of two case studies and multicase studies. This research was conducted as a case study. According to Metriam in Bogdan and Biklen (1992) case study is detailed examination of one setting or a single subject, a single depository of document or one particular event. This design was chosen because this research was conducted for one case of language in one region.

\section{FINDINGS AND DISCUSSIONS}

Many researchers have conducted about the language maintenance. This study also took in different language, community, and place. It can be concluded that this research had different findings with the previuos study and supported by previous theories.

From the findings above, there are seven factors that affect the Balinese people in maintaining Balinese language in Langkat, they are ethno lingustic vitality, using language in family domain, using language in neighborhood domain, using language in religion domain, using language in workplace domain, practice of traditional ceremony and an additional factor that found by researcher as a new insight in this research, it is using Balinese language with older people. Some factors that find out this research are not wholly line with the theory of Holmes even there is a new factor to maintain the language that found by researcher, it is interaction with older people.

The first factor ethno linguistic vitality. It is also factors that support the maintenance of Balinese language. Ethno vitality is related to the attitudes of the language speakers toward their language, their proud of being Balinese people and proud to use Balinese language, this case supports them in maintaining their language. As Holmes (2001:61) states that ethno linguistic vitality also related to the attitudes of the language users to their language. Balinese people in Langkat are proud of being Balinese people because of that, they use Balinese language in daily communication. They want to their language is developed and there are documents like dictionary or books that can be used by Balinese language so that their language have an evidence to show their language is exist in the 
course of the world. Meanwhile, when they go out from their region most of prefer to use other language like Javanese or Bahasa Indonesia because the other ethnics do not understand their language and some of them feel unconfident to use Balinese language in front of the other ethnics.

The second factor is the use of the language at home. The use of the language at home has a big role in maintaining the language. As Holmes (2001:32) states that the use of vernacular at home is also a good reason for nuclear or extended family to keep using their vernacular language at home as this will help to maintain their language. Balinese language use at home domain related to the language use in the respondents' family origin. The use of language at home can be separated from the speakers such as parents (father and mother) and the children. Family domain can come from the intramarriage family and intermarriage family. Usually, when the parents come from same ethnic (intramarriage) the venacular will be maintained, while the parents come from the differen ethnic (intermarriage)the vernacular can be shifted to the other language.

For this case, all participants who come from intramarriage family always use Balinese language when they communicate to eah other at home, like when wife speaks to her husband, husband to his wife and parents to children and children to parents. But the participant who comes from intermarriage family, the family uses Bahasa Indonesia to communicate to his wife and his children. Although, they use Bahasa Indonesia at home, but they sometimes try to communicate to their children to use Balinese language because it will make their children not blind in Balinese language. When their parents communicate Balinese language but their children response in Bahasa Indonesia. It means that their children undersand Balinese language but their children are difficult to speak Balinese language. Thus, it can be clarified that the use of the language at home (interamarriage and intermarriage) have a contribution in maintaining Balinese language in Langkat.

The third factor is the use of the language in neighborhood domain is also important factor in maintaining Balinese language. As Gomma (2011) states that transmitting vernacular language is through interacton with friends whohave some ethnics and participating in society activity. Balinese people used Balinese language when they communicate to each otherin their environment suh as to their friends. But, sometimes they use Javanese language or Bahasa Indonesia if they communicate to other if they do not understand Balinese language. Thus, they use Balinese language depends to whom they speak.

The fourth factor is the use of the language in religion domain. Religion domain is also place of prayer and also for discussing about the religion, laws of religion and religion organization. Most of the speakers used Balinese language in Pura.

The next factor is the use of the language in workplace domain. Balinese people live in agriculture sector. Most of participants are farmers, they used Balinese language when they are working. But sometimes, when the participants meet with diffent ethnic, they speak Javanese or Bahasa Indonesia because the dominant of people in there are Balinese and Javanese. Thus, the use of the language in the workplace domain is support to maintain Balinese language in Langkat. 
The next factor is traditional ceremony this is also one of the factors that affecting the language maintenance of Balinese in Langkat. There are many kind of traditional ceremony such as Mepandes ceremony, Megibung ceremony, Ngaben ceremony, and Melasti ceremony. The culture of Balinese above, Balinese people in Langkat still do that activity. Thus, this is one of factors that supports to maintain their language by keeping existence of their language.

And the last factor is the researcher found in the field the use of the Balinese language with older people. When Balinese people meet older people, they must speak Balinese. Balinese language is to show the people, polite or impolite to communicate to older people. It is as their respectful with older people. Thus, it is an important factor in Balinese, this will show their respectful to older people. It can be one of factor in maintaining the language, automatically makes the Balinese people encourage to study and practice Balinese language.

\section{CONCLUSIONS}

Factors affecting Balinese language maintenance in Langkat were not line with Holmes theory, in the theory there are five domains in maintaining language, but in the field there are seven factors found, they are ethno lingustic vitality, using language in family domain, using language in neighborhood domain, using language in religion domain, using language in workplace domain, practice of traditional ceremony and an additional factor that found by researcher as a new insight in this research, it is using Balinese language with older people. Ethno linguistic vitality and using language in neighborhood domain have big role in Balinese language maintenance. It means that using language in neighborhood domain, they able to speak and practice the language in their environment and their daily communication affected them to maintain their language and increased the language.

\section{REFERENCES}

Ary, D. (2006) Introduction to Research in Education. Wadsworth Cengage Learning. USA

Ary D. \& Rajaviah, A. (1979). Introduction to Research in Education. New York : Holt, Rinehart and Winson.

Arikunto S (2008), Prosedur Penelitian: Suatu Pendekatan Praktik, Ed. Revisi VI Cetakan Ketigabelas, Jakarta: PT. Rineka Cipta,

Brown, D. (1994). Principles of Language Learning and Teaching. New Jersey: Prentice Hall

Decarrico, J. S. (2001). Vocabulary Learning and Teaching. In M. Celce-Murcia (ed.), Teaching English as a Second or Foreign Language, Boston: Heinle and Heinle.

Dubin, F. \& Olshtain, E. (1993). Predicting Word Meanings From Contextual Clues: Evidence from L1 readers. 
Fraser, C. A. (1999). LPS Use And Vocabulary Learning Through Reading. Studies in Second Language Acquisition.

Frantzen, D. (2003). Factors Affecting How Second Language Spanish Students Derive Meaning From Context.

Haastrup, K. (1991). Lexical Inferencing Procedures or Talking About Words : Receptive Procedures In Foreign Language Learning With Special Reference to English. Tubingen, Germany : Gunter Narr.

Jackson,H. 2000. Words, Meaning and Vocabulary. London: New York. The Cromwell Press.

Nagy, W. (1997) On the Role of Context in First and Second Language Vocabulary Learning. Cambridge University Press.

Oxford (1995) Advance Learner's Dictionary New York: Oxford University Press.

Oxford, R. (1990). Language Learning Strategies: What Every Teacher Should Know. Massachusetts: Heinle \& Heinle.

Richards, J. C., \& Renandya, W. A. (Eds.). (2002). Methodology in language teaching: An anthology of current practice. Cambridge: Cambridge University Press. 